\title{
The Use of Multimedia Technologies in Teaching Russian as a Foreign Language: a Film-Viewing Study
}

\author{
Ekaterina A. Mikeshova* \\ Palacký University \\ 10 Křižkovský Str., Olomouc, 771 47, Czech Republic
}

Received 15.09.2016, received in revised form 01.11.2016, accepted 06.02.2017

The article discusses the use of multimedia technologies in teaching Russian as a foreign language considering film-viewing as an example. Multimedia technologies change the character of educational activities by increasing their efficiency. Integration of video materials and film-featuring into curricula of Russian as a Foreign Language classes serves different purposes such as development of communicative skills, cultural and linguistic awareness and social understanding as well as compensation for the lack of language milieu. The article presents teaching guidelines for a foreign language class based on showing the film Kiss Them All (Gorko!) by Zhora Kryzhovnikov in class.

Keywords: Russian as a Foreign Language, multimedia technologies, language proficiency, language skills, in-class film-viewing, video materials for foreign language classes.

DOI: 10.17516/1997-1370-0044.

Research area: philology.

Contemporary Society evolves in the times of informatization and globalization when IT and Multimedia technologies are introduced, on an increasingly wide scale, into education and teaching of foreign languages, and teaching Russian as a Foreign Language is not an exception in this respect. Multimedia technology is "an umbrella term for technologies that use multiple types of content forms simultaneously, such as graphics, texts, video, photos, animations, sound effects and accompanying sounds. Their application requires the use of special software and hardware tools. Multimedia technologies are adopted in e-textbooks and electronic courses"
(Azimov, Shchukin, 2009: 149). Multimedia technologies fundamentally change the learning process: now learning can take place anywhere and anyhow which prioritizes cooperation and enables students to play an active rather than a passive role; the essence of technologies is development of communication skills in students. Electronic textbooks and educational programs (trainings, multimedia presentations, and online resources) belong to the most popular multimedia.

The use of multimedia technologies in teaching Russian as a foreign language became a necessary condition for deepening, dynamizing

(C) Siberian Federal University. All rights reserved

* Corresponding author E-mail address: jekaterina.mikesova@upol.cz 
and diversifying the learning process. The fact that "video-communication, including a contact with films, television and computer graphics, becomes, nowadays, a significant and everexpanding part of communication in modern society" (Azimov, 2006: 38) plays an important role. That is internet-resources, TV Channel websites, YouTube, and various media, where the modern man receives information from. And there are no obstacles to use information from these sources for educational purposes, including teaching Russian as a Foreign Language. These resources may be, and are, applied for educational purposes, as they are available for teachers from all over the globe, they stand for clarity, being highly informative in nature, and, finally, they are simply easy to use. Evaluating them from a student's perspective, these sources of authentic data enjoy greater confidence than classical handbooks, especially, since the younger generation prefers to work with electronic data, mobile phones and smart phones, so the process of language learning using multimedia tools will be more efficient for them.

At first glance it may seem that the use of multimedia technologies makes teachers' lives easier in a great extend, and it may even give a wrong impression that a film, video or program gets the job done for a teacher. A specialist, however, can only agree in part with this position, as making the video or program to do its job requires a teacher to take many steps integrating it into the context of classes: to select suitable materials corresponding to the language proficiency level of a group, to develop assignments, and, above all, to have a clear understanding why the materials should be demonstrated and what are the goals to be achieved by the classes.

A problem of multimedia technologies' use in teaching Russian as a Foreign Language has currently generated a great interest among both, practitioners and theorists. New teaching guidelines are being developed for both, individual classes with the application of video materials, feature and animated films, and the entire courses based on films made by one director or set of films created during a certain time period. Among many interesting and useful manuals one can find the following: "Talking in Russian about Russian Films" by N.N. Glebova and I.A. Orekhova (2012), "The Use of Video Materials As A Means of Developing Communication Skills in the classes of Russian as a Foreign Language" by O.P. Ignatenko, "We Look! We Listen! We Speak!" by O. V. Kryakhtunova, a methodical guidance "We are from the future (The Use of Feature Films in the Language Learning Process)," by T.N. D'yachenko and "Training Modules For the Use of Video-Materials" by O. P. Bykova and many others.

Educational videos, news reports, TV debates and various talk shows as well as feature and animated films may be demonstrated in any class, at any stage of language learning to students at both, basic and advanced level. The selection of video materials in terms of their topics, genres, and duration depends on teacher's choice and goals and objectives that are appropriate for a class and can be achieved using the selected video materials. The selection is also conditioned by the level of training of students or course-groups, their age and interests, and by class topics. While selecting a video it is also important to take into consideration a cultural background of students.

From my own experience of teaching Russian as a Foreign Language to Czech students I can confirm the conclusion recently reached by practitioners and methodologists, namely, that it seems to be reasonable to use video materials in the classroom for almost all language levels, however, as a rule, for demonstrating feature films, the students' level of proficiency in Russian should be $\mathrm{B} 1$ and higher. 
Showing video materials in the classroom may pursue different aims: from illustrating lexical and grammatical phenomena (for instance, a Yeralash episode "Get caught, fish!" trains the use of the genitive constructions), to the examination of newly learnt conversation vocabulary and the perceiving a film with all its semantic and extra-linguistic properties and precedent texts.

Irina V. Kurlova considers that "a filmviewing is not only demonstration of a film followed by a discussion on it, but it presents material for language learning since that's exactly its primarily objective, while ethnocultural, cultural and anthropologic aspects are not, no matter how good they are" ( Kurlova, 2008: 25).

The relevance of video materials and films increases in those cases when Russian language is taught outside of its area of distribution. In the present case, namely living out of the country of the studied language, students may weaken or lose their intrinsic motivation, defined by I.A. Orekhova as "utilitarian and consumption motives which involve the use of a foreign language in order to ensure well-being as well as topical and functional motives arising from the inner desire inducing to use a studied language regularly" (Orekhova, 2007: 36).

In addition, the lack of language environment as a factor of extrinsic motivation, where students can draw linguistic and nonlinguistic knowledge, may hinder the formation of their linguistic skills, cultural, linguistic and social competences in a great extent. Social and cultural competence is "the body of knowledge about the target language country, the national and cultural peculiarities of the native speakers' verbal behavior, and an ability to apply this knowledge in the process of communication, following the customs, rules of conduct, norms of etiquette, social conditions, and behavioral stereotypes of the native speakers" (Azimov, Shchukin, 2009: 286).

Therefore video materials, from educational films to feature films, may become a good solution for overcoming the mentioned difficulties in teaching and learning Russian as a Foreign Language. Video materials and films provide an excellent opportunity for development of the listening comprehension skills in students as they hear the language spoken by native speakers, at a normal pace, with different intonations, possible disorders and articulation problems, and in a variety of functional styles, viewing films and video materials; video materials also facilitate the formation of cultural, linguistic and social competences, familiarize students with various historical events and social phenomena, allow them to gather background knowledge about the etiquette, Russian everyday life, gender attitudes and stereotypes, interaction between people of unequal social and financial status, non-verbal communication means, which are typical specifically for the Russians, and, finally, the video helps a teacher to diversify activities, to enliven lectures and to maintain the students' attention, to increase their motivation and interest in the subject, etc.

Last but not least, video materials and feature films may help to combat stereotypes about Russia, which, just 5-10 years ago, was perceived by the Czech youth, influenced by the older generation, as a country initiating the invasion of Czechoslovakia in 1968. Nowadays, the attitude toward Russia is purely pragmatic; the country is perceived as a huge and open market of opportunities in terms of business development, tourism, etc. Young people tend to be interested in modern Russian life, the problems and concerns of their contemporaries, and therefore, from this point of view, showing modern Russian films to such students seems very appropriate. However, basing on my experience with the Czech students, 
I cannot say that the old Soviet films, produced in the 1970-80s do not spark interest in students. These films are interesting, but they require more detailed explanation by the teacher. Besides, these films are rich with precedent texts, phraseology, colloquial names and spoken clichés; and knowing them and using them correctly in a speech gets a foreigner closer to a native-speaker's level of the language.

The following teaching guidelines for a foreign language class on the film Kiss Them All created by Zhora Kryzhovnikov in 2013 will illustrate the above. While working with a feature film an Educational Method based on a traditional scheme may be applied, and it includes the following stages: the before-viewing assignments will make the students interested in the film and working on it, will prepare them for experiencing the film by facilitating the understanding of individual words, expressions, realities (it is possible to give a list of rare words and difficult expressions to the students as a homework); the tasks performed while watching the film (its parts) and meant for understanding of individual situations and details as well as the general content of the film; the after-viewing assignments which may be framed in the form of questions and aimed for engaging the students into an active discussion and expressing their opinions about the film, for handling new vocabulary and using it in communicative situations as well as for checking the understanding and mastering of extra-linguistic information.

\section{Teaching Guidelines for a class on the film Kiss Them All (2013) by Zh. Kryzhovnikov}

This film was shown to the students in the framework of the module consisting of topics devoted to the family and family relationships, wedding ceremonies around the world, marriage contracts and different types of families (students of B1-B2 level). The film was selected due to the fact that it is ideally suited for the topic of the course. A wedding is a significant event in one's life, so the students displayed empathy with the characters and curiosity and tended to compare the film with their own experiences and knowledge about weddings in their country. And it was impossible for the film not to evoke a keen response and interest of the young audience. But it was also selected to reach the pragmatic learning objectives which are the following: the understanding of individual situations and the entire film, enlarging the vocabulary of spoken Russian and improving communication skills. The film being a rich source of extra-linguistic information made the students acquainted with the traditions and rules of weddings, the peculiarities of the Russian everyday life, music and dance culture of the youth.

The film may be divided into four parts, and their demonstration will be supplemented with questions and comments, if necessary. The number of fragments is conditioned by their thematic integrity (the wedding preparations, the first party, the second party, and the final) and the level of students' training. The division of the film into shorter fragments (wedding preparation: in the restaurant, at "jeweler" Sergeevich, at Antonina's tailoring studio) seems inappropriate.

\section{BEFORE THE FILM-VIEWING}

For better understanding of the film lists containing the most difficult words and the most widely used expressions may be distributed to the students. The translation of such words and expressions into the native language and their memorizing may be given as a homework.

As a further step, information about the film will be presented, which includes: its title, release date, name of the director and the cast, it also may be supplemented with data confirming 
the high ratings and popularity of the film among audiences.

\section{QUESTIONS:}

- What do you think the film with such a strange name will be about? Does it have something to do with our topic?

- What do you expect from the film?

- What associations do you have with the word "wedding"?

\section{DURING THE FILM-VIEWING}

2.1. The group watches the first part of the film:

The film's main characters, Roman and Natasha, are planning to get married. They talk about themselves on camera thus creating their own wedding and pre-wedding video. Unfortunately, the parents and children have different plans for the wedding party. The parents of Roman and Natasha get acquainted with each other, and it can be easily noted how different they are in their social and financial standing, temper and level of education. Despite the fact that Natasha and Roman do not fancy the idea of the party planned by Natasha's father, the wedding preparations are in full swing. The dinner at a restaurant is being negotiated, a toast-master is arranged, a wedding dress and rings are selected, and the intended date of marriage is appointed at a Registry Office. Meanwhile Natasha and Roman hold secret negotiations with Natasha's boss, Semyon, concerning the organization of a second wedding party at their own taste and intended for friends only. Semyon promises to plan everything at a local yacht club, on the beach, inviting all the tops [senior managers], the company's board from Moscow and a fancy DJ. However, by chance, both wedding parties, for family and for friends, cannot be scheduled differently and fall on the same day. To pay for the second party, Natasha and Roman sell a new car, a gift received from Natasha's father, to
Semyon. The first part ends with hen and stag parties and Natasha being angry on her fiancé whose last night of freedom was too wild. The bride and groom leave to spend the last night before the wedding with their families. And if in the beginning the viewer saw the apartment where Natasha lives, now he/she gets acquainted with Roman' house, where he is taken by sea boat driven by his father. The viewer sees Roman's brother, the ex-convict, Alex and his girlfriend Ksyucha. Another Roman's brother Dimka is behind the camera.

\section{QUESTIONS AFTER THE FIRST PART}

- What are the names of the film's main characters In your opinion, how old are they? What are their professions?

- What do we know about the bride and groom? What is their attitude toward each other? What can we say about their characters?

- How do Natasha and Roman imagine their wedding party?

- How does Natasha's mother think the wedding party of her daughter should look like?

- Where do Natasha's parents live? Describe and characterize their apartment.

- Whom does Boris Ivanovich mobilize while planning the wedding of his daughter? Whom does he address to? Why did he choose these people?

- What kind of party does Semyon promise to organize? Who is he?

- What kind of solution did Natasha and Semyon invented? How do they want to pay to Semyon?

- Where does Roman's family live? Why does Roman visit these people on the eve of his wedding?

- Who is Alex? What do we know about him and his life?

- In your opinion what will happen next in the film? 
Additional Assignments: a) Write down the names of all the film's characters. In the second column, write nouns denoting kinship relations, for example, father-in-law, motherin-law, sister-in-law, etc. Match the words from two columns (e.g. Roma is a son, son-in-law, and husband). The same task can be exercised using flashcards.

б) Write down offices and professions of the characters. Describe the activities connected with a profession. For example, Roman is a journalist. He gathers materials, writes articles, does the interviews etc. Antonina is a tailor and an owner of a tailoring studio. She sews custommade clothes and dresses, including wedding dresses.

2.2. The group watches the second part of the film:

Roman with his brothers and numerous relatives from Tuapse go to Natasha's house. It's not easy to get the bride, and Roman should overcome numerous obstacles, however the well-known game Win the Bride is accompanied by rude pranks and not always appropriate comments by Roman's drunken relatives. Afterwards all the personages set off for a Registry Office where the official wedding ceremony takes place. It is followed by the appearance of the newlywed on the porch, in front of the Office, where the guests shower them with rice and the couple releases a pair of white doves to the sky. The drunken guests behave quite violently, at first throwing gray pigeons to each other, then breaking a head of a sculpture, and, finally, stalking an unfortunate advertising man wearing a hotdog suit. Natasha and Roman are in hurry, they need to spend some time with the relatives and to get away for the second wedding party. Before entering a restaurant, the couple takes traditional bites from a loaf of bread brought by
Natasha's mother, and sees the man who will be the toastmaster at their wedding party. This is an actor and showman Sergei Svetlakov. At the restaurant, congratulations and parental advices are given followed by high jinks, dancing and competitions, which includes a belly dance and a performance of the troopers' ensemble invited by Natasha's father. Natasha throws her bridal bouquet, and she and Roman seek to speed up all the necessary rituals, in every possible way, but they cannot escape unnoticed. Soon the guests notice their absence.

QUESTIONS AFTER THE SECOND PART:

- Why isn't Roman allowed to pass freely to his bride? What are the obstacles the groom should overcome?

- In your opinion, who is the family leader, Roman or Natasha?

- Why did Boris Ivanovich invite S. Svetlakov for the wedding?

- What are the wedding traditions and customs that you can list?

- How do the guests behave?

- What are the competitions held at the wedding?

- In your opinion, what is the role of the toastmaster Svetlakov? Can he be described as a ceremonial bystander called in Russian a wedding general? What does it mean?

- How do Roman and Natasha feel about their own wedding party?

- Do you like how the guests are dressed? How would you characterize their dressing style?

- What do you think about Boris Ivanovich' performance? What is this song?

Additional Assignments: a) Invent your own competition which could take place during the wedding reception.

b) Develop your own congratulatory speech and address the newlyweds with the befitting wishes. 
2.3. The group watches the third part of the film:

The second wedding party begins for Natasha and Roman with a great delay. Having arrived to a festively decorated yacht Natasha realizes that she doesn't know any of the guests, dislikes the music which is too loud, and finds the people from the Moscow company board unpleasant and the girls accompanying them - unbearable. Natasha proposes to Roman to return to the restaurant Zolotoi where their relatives celebrate the event. At the same time, the cameraman Dima, who was not invited by Roman and Natasha to the yacht, being threatened by Alex, discloses the plans of the newlyweds. The parents are confused not understanding the actions of their children.

All the guests head for the beach where the yacht is. Natasha and Roman seeing the procession of the guests headed by their parents feel abashed. Despite the fact that they try to get off the hook and to convince Natasha's father that the yacht is a surprise for all the guests, no one believes them. The parents are unpleasantly surprised and can't get over the fact that their children are ashamed of them and didn't invite their families for the secret wedding reception. Natasha's father nevertheless helps daughter to hold a ceremony on the beach, but when he learns that, as a payment for the party, she gave away the car presented by him, he says to her face what he is thinking. The father's comrades jump into the water, swim to Roman approaching the shore in his boat and overturn the boat, thereby disrupting the entire ceremony.

Natasha and Roman argue, and Natasha asks her husband to run after her father and to bring him back at any price. Instead, Roman returns to the yacht, finds the father-in-law and inflicts a severe blow to his nose. A fight of all against all starts and culminates the party on the yacht. Drunken Alex being jealous of his girlfriend Ksyucha paying attention to his brother threatens
Roman with a weapon. But in the end it is not Roman whom he shoots, but Natasha's father who tried to distract him. There is chaos and turmoil.

QUESTIONS AFTER THE THIRD PART:

- How do you think, what does Natasha expect from the yacht party?

- How does her mood change on the yacht? What does she see and dislike?

- What do you think, why among the invited guests were people, completely unfamiliar to Natasha and Roman?

- Does Roman's character evolve in the course of the wedding day? Does he always satisfy the whims and requests of Natasha?

- Did the family members realize that they were not welcome on the yacht?

- What did Boris Ivanovich say to Natasha? What was the matter of his reproach?

- Why did the friends of Boris Ivanovich overturn Roman's boat?

- Why did Roman decide to fight with Boris Ivanovich?

- How did the relatives behave on the yacht?

- What was the reason for the conflict and subsequent shooting?

- Did you expect such a turn?

2.4. The group watches the fourth part of the film:

The newlyweds, together with their relatives, find themselves in a police bus. Not only police but also the Emergency Response Unit, called by Sergei Svetlakov's brother, arrived to the incident scene. Drunken guests played a joke on Sergei, stealing his phone and telling his mother that her son was kidnapped. And now, these pranksters are detained. Natasha tries on earrings given to her by the mother-in-law, and, bursting into tears, she asks the parents for pardoning and acknowledges that all this was hers and Roman's fault. The parents excuse their children; everybody hugs, cries and 
sings the song Natalie. There are no reasons to worry about Alex, since Boris Ivanovich covered him up and saved from another prison term convincing the police that it was he himself who made the shot by inadvertency. Sergei Svetlakov says farewell to the newlyweds and their parents and tries to return the fee claiming that it was the most wonderful wedding he has ever visited.

In the finally, Natasha, Roman, Alex and the parents appear on the sea shore, on a pier. Natasha and Roman, still wearing their wedding gowns, want to jump into the sea, to make at least the jump to be THEIR OWN ceremony, but again the things are spoiled by Boris and Alex, who jump first. But then Natasha and Roman join them. The Mothers send greetings from the pier. Everybody is cheerful and happy.

QUESTIONS AFTER THE FOURTH PART:

- Why did police and the Emergency Response Unit arrive?

- What did happen to the guests, how do they look like?

- What kind of atmosphere was felt in the police bus? Where are Natasha, Roman, their parents and Alex?

- Why does Alex look so lost and detached?

- What does Sergei Svetlakov say to Boris Ivanovich during the farewell?

- How does Natasha behave?

- Did Boris Ivanovich do what is right presenting the shot as if by inadvertency? How has the mood changed in the bus after his words?

- How does the film end? In your opinion, what does the joint jump of the newlyweds into the sea mean?

\section{AFTER THE FILM-VIEWING}

QUESTIONS (for students with B1 and higher level of proficiency in Russian):

- Do you like the film? Justify your answer.
- Briefly summarize the content of the film.

- What are the specific features of a wedding depicted in the film? What do you think; can it be characterized as a typically Russian?

- How weddings are celebrated in your country? Are there any similar traditions?

- In your opinion, will this wedding be remembered by the couple and their guests? If yes, then in which way?

- Can one state that the conflict of generations is depicted in the film? What do you think, why parents did not take into account the wishes of their children?

\section{Additional Assignments:}

- Introduce the position of the parents and present their arguments in support of their vision of the event.

Try to defend different ideas about the wedding from the point of view of the bride and groom. State your reasons to the parents. Can you invent your own plan of the wedding?

The Assignment can be practiced in form of a dialogue.

- Indentify a character by expressions:

- Categorical greetings, Michal Michalych. (Natasha's father)

- Roma, how long does it take? Pull it faster! (Natasha)

- There are only rocks around. As in the bosom of Jesus! Cool! Let's invite all the tops! (Semyon)

- A woman with a car wheel is like a monkey with a grenade. It is funny and scary at the same time. (Natasha's father)

- we should celebrate the meeting with a drink, why to postpone it? (Roman's mother)

- The most important thing is not to feel ashamed looking at people's eyes afterwards, on the morning after. (Roman's mother)

- What the hell it is? I will look like a teapot doll. (Natasha) 
- Find an episode when Natasha finds out that the dates of the wedding parties coincide talking on the phone with Semyon and asking him to return the car.

Assignment: reconstruct Semyon's replies.

- Boris Ivanovich: I invest money and soul, what else should I invest?

Natasha: Dad, what the Hell are you talking about?

Boris Ivanovich: That's not about the Hell, that's about happiness.

Assignment: explain, what gives a comic effect to these expressions.

- Write a short text describing how, in your opinion, could develop later family and professionallife of NatashaandRoman. Remember about their professions and occupations.

- From the point of view of an owner of a wedding planning agency present your company and list the services it provides, who is the target group of the services, what are the prices.

- The following assignment is meant for the students with the levels B2-C1: read comments of the viewers for the movie. Select the one which reflects your opinion or is close to your point of view. Look for the arguments which you also may support.

\section{Comment No. 1}

After watching this chaos I feel desperate and really want to get drunk. The movie is presented as a home-video, which assumes that the main characters have to look natural, but all my hopes on an acceptable acting had collapsed from the very beginning. But how realistic it was when everybody got drunk! I am just curios, what did the filmmakers count on? The most interesting thing is that the audience hooted with laughter like the groom's mother, applauded the old well-known jokes and sang along with the film, Natalie, quench my sorrow, Natalie. To get buzz of the movie you need to be in tune with it having experienced a couple of weddings with numerous relatives. Almost every line of the film could become a catch phrase for a drunken company belonging to the age group $30+$. This movie is one-off thing, even a half-off... There is no reason to watch such Grand Russian Comedies in the cinema.

\section{Comment No. 2}

Actually, the concept is excellent, I like the amateur video shooting style, I also like the idea concerning the wedding, the Russian wedding. The cast is well matched, the protagonists are very vivid and all the actors together look organically, and the film perfectly captures an anticipantion of the big event. I especially want to mention the bride's father, he perfectly portrayed a character of a cool commando who uses all his connections, tries to keep a high profile and organizes everything on his own. Some moments are very touching, and, it seems to me, that many families have such funny family members. The gunman at the wedding, who is the brother of the groom, is the only character I found familiar. There is some sort of echo of the 90s, that's really cool.

\section{Comment No. 3}

Such an important event as a wedding provides great opportunities for picturing different social types of Russian reality, whose behavior in the film seems inappropriate and absurd to that extent that you either cry or laugh. The aspects of personalities of these characters are presented so accurately that sometimes I could recall the prototypes of those people whom I have met in my own life. As the result there is a satirical comedy about two generations, an experienced generation of parents living in their own way, and a naive generation of children who are dreamers. And, the same eternal question posed by Turgenev now rests somewhere in the middle of opinions, together with the truth. For those who have doubts, I would like to note that there is quite a bit of vulgarity in the movie, no 
more than in the real life itself, and even though alcohol flows like a river, it hardly affects the main characters and their parents.

(Comments from the Web Page www.kinopoisk.ru).

In a way, the feature film compensated for the students the lack of a direct contact with the environment of the studied language, and it became a source of extra-linguistic information. Under the present circumstances, the use of the film for developing cultural and social competencies seems to be a mandatory component of the language training. The information acquired by the students about the traditional wedding celebrations in Russia was supplemented by details concerning the life of a small provincial town, the lifestyle and wellbeing of officials, the fathers-and-sons conflict still remaining relevant, and the relationship between young people.

The questions posed to the film, divided into the parts, allowed the students to check their understanding of the parts and the entire film. The after-viewing assignments were focused on developing and improving the linguistic competencies, simulating real-life situations and contemplating the linguistic peculiarities of the demonstrated film.

The use of multimedia technologies and, in the present case, of the film, in the classroom of Russian as a Foreign Language has high potential also for the formation of the understanding and listening comprehension skills. Of considerable importance is the fact that watching a film and working with it makes the classes more interesting for the students and helps to enhance their motivation.

\section{References}

Azimov E. G. (2006). Metodika organizatsii distantsionnogo obrazovaniya russkomu yazyku kak inostrannomu. [The distance teaching of Russian as a second language organization methods] Moscow, Russkiy yazyk.

Azimov E.G., Shchukin A.N. (2009). Novyy slovar' metodicheskikh terminov i ponyatiy (teoriya i praktika obucheniya yazykam). [New dictionary of methodological terms and concepts (theory and practice of language teaching)]. Moscow, Ikar.

Bogomolov A.N. (2007). Rabota s autentichnymi i televizionnymi materialami na urokakh RKI (sredniy i prodvinutyy etapy obucheniya). [Working with authentic and TV materials in the RSL lessons (the intermediate and advanced levels)] Available at: www.dist-learn.ru (accessed 27 February 2016)

D'yachenko T.N. (2015). «My iz budushchego» (ispol'zovaniye khudozhestvennykh fil'mov $\mathrm{v}$ yazykovom uchebnom protsesse) [We are from the future (Use of feature films in the language teaching process)], In Journal Russkiy yazyk za rubezhom, 3, 24-38.

Ignatenko O.P. (2015). Ispol'zovaniye videomaterialov kak sredstvo formirovaniya kommunikativnykh navykov na zanyatiyakh RKI. [Use of video materials as a means of forming communicative skills in the RSL lessons] Available at: http://sociosphera.com/ publication/conference/2015/128/ispolzovanie_videomaterialov_kak_sredstvo_formirovaniya kommunikativnyh_navykov_na_zanyatiyah_rki/ (accessed 27 February 2016).

Kryakhtunova O.V. (2012). Smotrim! Slushayem! Govorim! (na materiale khudozhestvennykh, nauchno - populyarnykh i mul'tiplikatsionnykh fil'mov na russkom yazyke). Metodicheskoye posobiye po russkomu yazyku dlya raboty na urokakh russkogo yazyka kak inostrannogo (elementarnyy $i$ bazovyy urovni). [Watching! Listening! Speaking! (based on the feature films, popular science films

$$
-376-
$$


and cartoons in Russian). Teacher's guide for lessons of Russian as a second language (elementary and basic levels)] Astrakhan': Astrakhanskiy gosudarstvennyy tekhnicheskiy universitet.

Kurlova I.V. (2008). Rabota s uchebnymi, mul'tiplikatsionnymi i khudozhestvennymi fil'mami na uroke RKI. [Working with educational films, cartoons and feature films in the RSL lessons] Available at: http://library.cie.ru/file.php/b8d63bd74941a6789acf374984294859.pdf?load=true (accessed 27 February 2016)

Novikova V.V. (2013). Ispol'zovaniye videomaterialov pri obuchenii russkomu yazyku kak inostrannomu kak sredstvo formirovaniya sotsiokul'turnoy kompetentsii yazykovoy sredy [Use of video materials in teaching Russian as a second language as a means of forming social and cultural competence in the language environment], In Russkiy yazyk v sovremennom mire: traditsii i innovatsii $\mathrm{v}$ prepodavanii russkogo yazyka kak inostrannogo i v perevode. Materialy III mezhdunarodnoy nauchno-prakricheskoy konferentsii, 216-222.

Orekhova I. A. (2007). Yazykovaya sreda est'. Yazykovoy sredy net [The language environment exits. The language environment does not exist], In Journal Russkiy yazyk za rubezhom, 3, 35- 38

Shchukin A.N. (2003). Metodika prepodavaniya russkogo yazyka kak inostrannogo. [Methods of teaching Russian as a second language] Moscow, Vysshaya shkola.

\title{
Мультимедийные технологии \\ в обучении русскому языку \\ как иностранному на примере \\ использования художественного фильма
}

Е.А. Микешова

Университет им. Палацкого

Чехия, 771 47, Оломоуи, ул. Кржижсковского, 10

\begin{abstract}
В статье рассматривается вопрос использования мультимедийных технологий в обучении русскому языку как иностранному на примере использования художественного фильма. Мультимедийные технологии меняют характер учебного процесса, повышают его эффективность. Использование на занятиях РКИ видеоматериалов или демонстрачия художественных фильмов преследует различные цели: развитие коммуникативных, социокультурных и лингвокультурных компетенций студентов, компенсирование естественной языковой среды. $\mathrm{B}$ статье приводится методическая разработка занятия, построенного на демонстрации фильма режиссера Ж. Крыжовникова «Горько!».
\end{abstract}

Ключевые слова: РКИ, мультимедийные технологии, языковые компетенции, видеоматериаль и художественные фильмы на занятиях РКИ.

Научная специальность: 10.00.00 - филологические науки. 